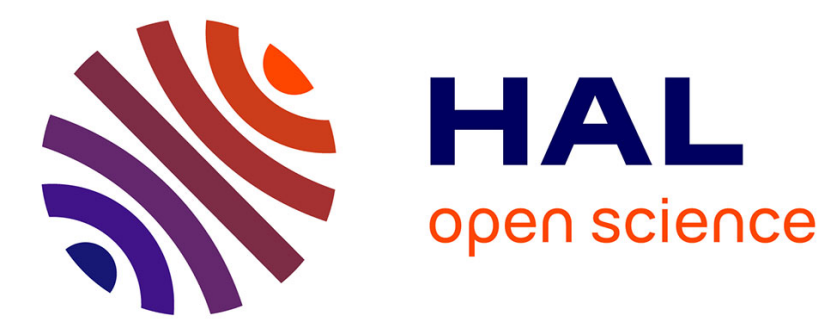

\title{
IMPACT FRAGMENTATION OF BRITTLE MATERIALS
}

\author{
R. Woodward, B. Baxter, S. Pattie, P. Mccarthy
}

\section{To cite this version:}

R. Woodward, B. Baxter, S. Pattie, P. Mccarthy. IMPACT FRAGMENTATION OF BRITTLE MATERIALS. Journal de Physique IV Proceedings, 1991, 01 (C3), pp.C3-259-C3-264. 10.1051/jp4:1991336 . jpa-00250478

\section{HAL Id: jpa-00250478 https://hal.science/jpa-00250478}

Submitted on 1 Jan 1991

HAL is a multi-disciplinary open access archive for the deposit and dissemination of scientific research documents, whether they are published or not. The documents may come from teaching and research institutions in France or abroad, or from public or private research centers.
L'archive ouverte pluridisciplinaire HAL, est destinée au dépôt et à la diffusion de documents scientifiques de niveau recherche, publiés ou non, émanant des établissements d'enseignement et de recherche français ou étrangers, des laboratoires publics ou privés. 


\title{
IMPACT FRAGMENTATION OF BRITTLE MATERIALS
}

\author{
R.L. WOODWARD, B.J. BAXTER, S.D. PATTIE and P. MCCARTHY \\ DSTo Materials Research Laboratory, P.O. Box 50, Ascot Vale, \\ Victoria 3032, Australia
}

\begin{abstract}
RESUME :
Des impacts à grande vitesse de projectiles sur des blocs finis et "semiinfinis" sont décrits. La pénétration s'accompagne d'une érosion du projectile et de la fragmentation et de l'éjection du cratère de petits débris; l'énergie cinétique de ces débris représentant plus de $50 \%$ de l'énergie cinétique initiale du projectile. La réflexion des ondes de contrainte sur les surfaces libres et l'interaction de ces ondes réfléchies provoquent l'écaillage et la fragmentation du bloc. Le volume éjecté de matériau finement fragmenté est proportionnel à la taille du cratère et est donc relié à l'intensité de l'impact, c'est-à-dire à la masse et à la vitesse du projectile. La rupture dans les fragments plus gros situés loin du cratère est aussi reliée à l'intensité de.l'impact, qui détermine le niveau de contrainte et les tailles des défauts activés, et est donc reliée, à la fois, à la vitesse et à la taille des fragments. L'énergie de déformation élastique est transformée en énergie d'expansion du nuage de débris.
\end{abstract}

Abstract - Impacts of high speed soft projectiles on finite and "semi-infinite" brittle blocks are described. Penetration is accompanied by projectile erosion and by the comminution and ejection of fine debris from a crater, the kinetic energy of this debris accounting for over $50 \%$ of the projectile impact kinetic energy. The conservation of momentum requires a small forward velocity of the centre of mass, and reflection of stress waves from distal surfaces and interaction of these reflected waves results in spalling and fragmentation of the block. The volume of finely fragmented material ejected is proportional to the size of the impact crater, and thus related to the intensity of the impact, i.e. the mass and velocity of the projectile. Fracture into larger fragments away from the impact crater is also related to the impact intensity, which determines the stress level and the sizes of flaws which are activated, and hence both the fragment velocity and size. The elastic strain energy is converted into the kinetic energy of expansion of this debris cloud.

\section{Introduction}

The nature of brittle materials is such that fracture may be controlled as much by the distribution of inherent microscopic flaws as by material strength and toughness. Under impact conditions where stress wave interactions are dominant, failure may initiate simultaneously at a range of sites as the stress distribution varies rapidly with time and position. Impact fragmentation of brittle solids has been studied using computational models at the ballistic $^{1}$ and astrophysical scales ${ }^{2}$, by combining the fundamentals of excess energy distribution, flaw size and the statistics of failure $e^{3,4}$, and by using energy and momentum balance techniques 5,6 . The present work takes the opportunity to examine projectile impact on "semiinfinite" brittle solids as a model for determining the redistribution of projectile kinetic energy through the impact process. 


\section{Experimental Methods and Materials}

Firings were undertaken at four brittle materials viz. baked clay paving bricks, olivine-basalt, granodiorite and quartzite. The strengths of these materials were characterized by indentation testing to give a hardness, Brinell for the brick and the basalt, Vickers for the quartzite. The brittle nature of the granodiorite prevented a reading being obtained. Three point bend tests were used to obtain toughness and the displacement of water was used to obtain density. The data characterizing these materials are given in Table I. For the determination of penetration depth, firings were undertaken at samples of dimension $300 \mathrm{~mm}$ cube (except for the brick) at which size few of the cracks in the rocks propagated to the edge and a depth of penetration is easily determined. For the brick $(230 \times 115 \times 68 \mathrm{~mm})$ a determination of depth of penetration was only possible for the smallest projectile by reconstruction of the fragments. For the examination of fragmentation, all targets were cut to the size of the brick.

\section{TABLE I}

Material Physical and Mechanical Properties

\begin{tabular}{|c|c|c|c|}
\hline Material & $\frac{\text { Hardness }}{(\mathrm{GPa})}$ & $\frac{\text { Toughness }}{\left(\mathrm{MPa} \mathrm{m}^{0.5}\right)}\left(\mathrm{K}_{\mathrm{Ic}}\right)$ & $\frac{\text { Density }}{\left(\mathrm{kg} \mathrm{m}^{-3}\right)}$ \\
\hline Baked Clay Paving Brick & 1.3 & 1.1 & 2,400 \\
\hline Olivine-Basalt & 1.0 & 1.7 & 2,700 \\
\hline Granodiorite & - & 0.5 & 2,700 \\
\hline Quartzite & 5.1 & 2.2 & 2,600 \\
\hline
\end{tabular}

Impact was by projectiles of diameters $5.56 \mathrm{~mm}, 7.62 \mathrm{~mm}$ and $12.7 \mathrm{~mm}$ fired from service rifles. The projectiles all had copper jackets, with the two smaller projectiles having a lead core and the larger projectile a mild steel core. For calculations the projectiles were modelled as cylinders with the same mass and diameter as the actual rounds. The projectile hardness value used was the weighted average using the masses of core and jacket. The projectile strength value was determined by dividing the weighted average Vickers hardness by 2.9 . The projectile details are listed in Table II.

TABLE II

Projectile Characteristics

\begin{tabular}{|c|c|c|c|c|c|c|}
\hline$\frac{\text { Proiectile }}{\text { Type }}$ & $\begin{array}{l}\text { Diameter } \\
(\mathrm{mm})\end{array}$ & Mass & $\frac{\text { Impact }}{\text { Velocity }}$ & $\frac{\frac{\text { Vickers }}{\text { Hardness }}}{\text { (GPa) }}$ & $\frac{\text { Derived }}{\text { Strength }}$ & $\frac{\frac{\text { Kinetic }}{\text { Energy }}}{(\mathrm{kJ})}$ \\
\hline $\begin{array}{l}\text { 5.56 Ball } \\
7.62 \text { Ball } \\
0.50 \mathrm{Cal} \mathrm{Ball}\end{array}$ & $\begin{array}{c}5.56 \\
7.62 \\
12.7\end{array}$ & $\begin{array}{r}3.63 \\
9.65 \\
41.88\end{array}$ & $\begin{array}{l}971 \\
838 \\
895\end{array}$ & $\begin{array}{l}0.48 \\
0.42 \\
1.94\end{array}$ & $\begin{array}{l}166 \\
145 \\
639\end{array}$ & $\begin{array}{r}1.71 \\
3.39 \\
16.77\end{array}$ \\
\hline
\end{tabular}

Targets were placed within 0.5 metres of the muzzle and impacted normally. For cases where the debris was collected, the target was completely contained except for the hole made in a thin aluminium disc covering the front of the box by the impacting projectile. In some cases high speed video was used to view the motion of the debris and this film was analysed to provide residual kinetic energy data. Post impact debris analysis was by sizing through sieves.

\section{Results and Discussion}

Depth of penetration data measured in the experiments are given in Table III along with estimates, in brackets, of depth of penetration from a simple analytical model ${ }^{7}$ of the impact on a semi-infinite brittle material. The experimental data is generally accurate to within $\pm 2 \mathrm{~mm}$. The first thing to note is that the model overestimates the depth of penetration by a factor of approximately two. This is not unreasonable given the simplicity of the approach used, the idealization of the projectile and the use of the strength parameters derived from hardness as the pressure at which the brittle material erodes. In the model solution the projectile erodes 
from the front, and for quartzite which is very hard, the projectile should erode completely. This was found to be a gross simplification for projectiles with steel cores. Whilst substantial erosion in chunks occurred for the projectile impacting quartzite, a considerable residual mass remained. Even for the softer targets where there was limited projectile erosion, it was observed that the effective projectile/target interface area was clearly greater than the sectional projectile area assumed in the model, because of deformation. As the calculations for the softer materials over estimate depth by a factor of two they indicate that even for the paving brick the projectile would not be expected to perforate and, although the depth of penetration could not be determined because of the large amount of break-up, a witness screen behind the target showed that this was the case.

\section{TABLE III}

\section{Depth of Penetration Data ${ }^{*}$}

\section{Penetrator Diameter}

Target

Paving Brick

Basalt

Granodiorite

Quartzite

\section{$5.56 \mathrm{~mm}$}

$23(41)$

16

$8(11)$

\section{$\underline{7.62 \mathrm{~mm}}$}

Depth (mm)

$$
\begin{aligned}
& -(48) \\
& 24(52) \\
& 40
\end{aligned}
$$

$10(8)$
$12.7 \mathrm{~mm}$

30

9 (8)

* Data in brackets calculated using simple model ${ }^{7}$.

It is not the purpose of this work to adjust the material erosion pressure to obtain a value where agreement between the model and experiment is exact, rather it is to study the mechanisms of the interaction. We thus have a projectile impacting the brittle material and coming to rest in less than $50 \mathrm{~mm}$ travel in all cases with eroded projectile and target material being ejected. The distance of travel is less than the minimum dimension of the brick and the time for the interaction, 50 to $150 \mu \mathrm{s}$, is short compared to the frame to frame time in the high speed video ( 1 millisecond). Thus the ejection of debris from the penetration should be observed in the first one or two frames after impact, subsequent frames showing the response of the target and projectile after penetration has ceased. Such a video sequence is shown in Figure 1. Evident in Figure 1 is a small rearward ejection of fine debris straight after impact, followed by expansion and forward movement of the brick. The rearward ejection velocity of debris was measured to be of the order of $150 \mathrm{~ms}^{-1}, 200 \mathrm{~ms}^{-1}$ and $250 \mathrm{~ms}^{-1}$ for the $5.56 \mathrm{~mm}, 7.62 \mathrm{~mm}$ and $12.7 \mathrm{~mm}$ projectiles respectively. The expansion velocities of the brick around the instantaneous centre of mass and the forward translational velocity of the centre of mass were about equal to each other for the two smaller projectiles and were of the order of $3 \mathrm{~ms}^{-1}$ and 7 $\mathrm{ms}^{-1}$ for the $5.56 \mathrm{~mm}$ and $7.62 \mathrm{~mm}$ rounds respectively. For the $12.7 \mathrm{~mm}$ round the expansion velocity was about $7 \mathrm{~ms}^{-1}$ and the translational velocity about $14 \mathrm{~ms}^{-1}$. This data is used below in analysing the redistribution of energy in impact. 


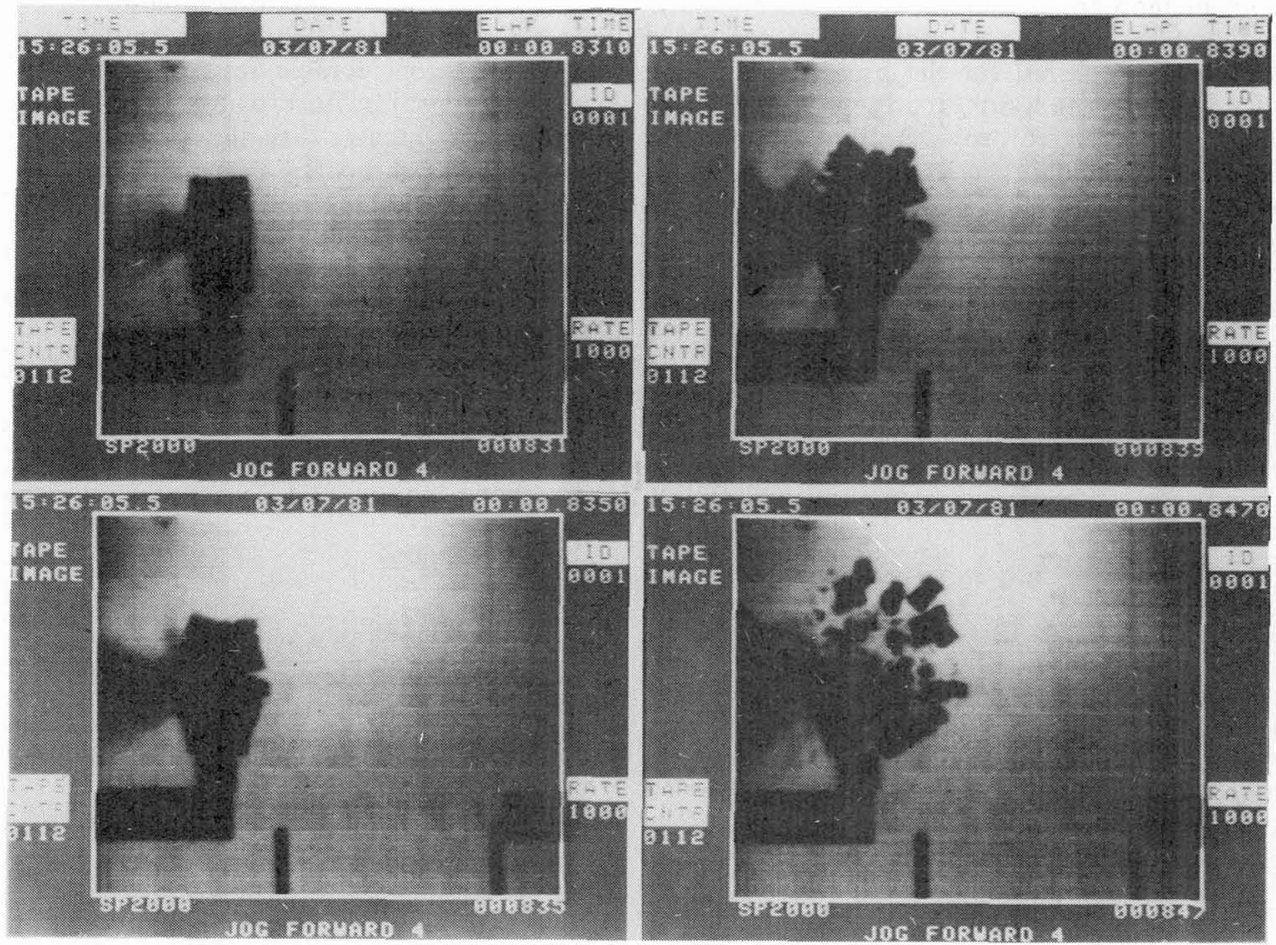

Fig. 1 Sequence of high speed video frames showing target behaviour after impact of a $7.62 \mathrm{~mm}$ projectile on the clay paving brick. Times after impact: $\langle 1,5,9$ and 17 milliseconds.

Figure 2 shows a piece of basalt, of brick dimensions, which has been reassembled after impact together with some of the fine debris illustrating the grading using sieves. It is clearly evident that reconstruction allows measurement of the depth of penetration even though the brick has fragmented. The bottom of the penetration crater is marked by white dust. It is also clear that even when the brick or rock breaks apart, this fracturing is secondary and the projectile has not necessarily perforated. The large majority of the fine debris comes from the region immediately around the hole or crater where penetration has taken place. Plots of cumulative volume of fine fragments as a function of fragment size showed that a greater volume of fine fragments was observed for the materials of lower toughness, in line with earlier work on ceramics ${ }^{5}$. This debris analysis also showed that the volume of fragments increased approximately in direct proportion to the impact kinetic energy, for any one material.

Fig. 2 Reassembled basalt block showing the impact crater, larger fragments ejected adjacent to the impact crater, right, and some of the fine debris from the crater decreasing in size from right to left.

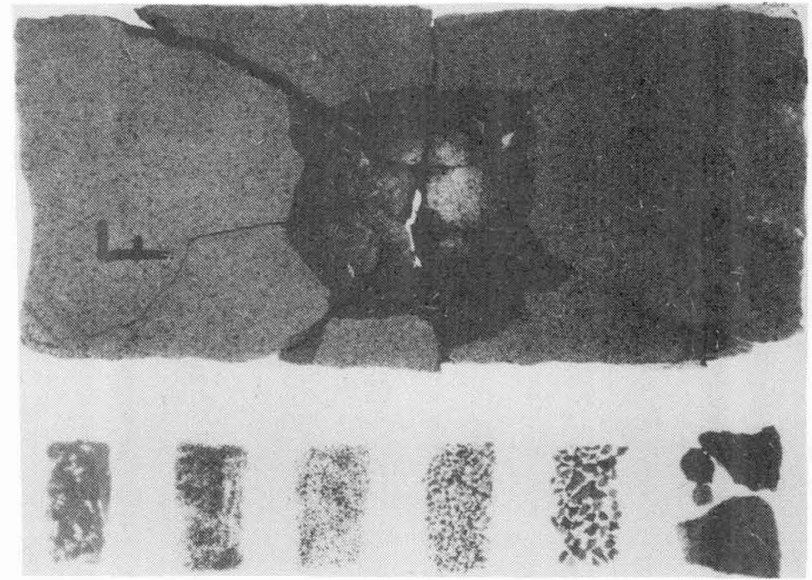


From the brick mass and the expansion and translation velocities derived from the high speed video, the kinetic energy associated with expansion and translation of the brick can be calculated and these values are listed in Table IV. The work done in projectile deformation and the residual kinetic energy of projectile fragments can also be calculated approximately, Table IV, and the energy of surface created in such brittle materials has been shown to be smal1 ${ }^{5}$. There is still a large shortfall in accounting for the impact kinetic energy of the projectile as given in Table II. The ejection of ceramic debris can however be shown to account for over $50 \%$ of the impact kinetic energy. Using the ejection velocities from the video, Table IV shows the kinetic energy if all fragments less than $2 \mathrm{~mm}$ are ejected with this velocity, and if all fragments less than $4 \mathrm{~mm}$ are ejected with this velocity. Taking account of the broad approximations in the energy sums it appears that the major phenomenon in this interaction is the transfer of kinetic energy from the impacting penetrator to the fine ceramic debris ejected from the impact crater.

TABLE IV

Energy Distribution (k.)

\begin{tabular}{llllllc}
\hline $\begin{array}{l}\text { Projectile } \\
\text { Diameter }\end{array}$ & $\begin{array}{l}\text { Brick } \\
\text { Translation } \\
\text { KE }\end{array}$ & $\begin{array}{l}\text { Brick } \\
\text { KEpansion }\end{array}$ & $\begin{array}{l}\text { KE of all } \\
\text { Debris } \\
<2 \mathrm{~mm}\end{array}$ & $\begin{array}{l}\text { KE of all } \\
\text { Debris } \\
<4 \mathrm{~mm}\end{array}$ & $\begin{array}{l}\text { Projectile* } \\
\text { Deformation } \\
\text { Energy }\end{array}$ & $\begin{array}{l}\text { Projectile\# } \\
\text { Fragment } \\
\text { Ejection KE }\end{array}$ \\
\hline $5.56 \mathrm{~mm}$ & 0.017 & 0.017 & 0.5 & 0.8 & 0.07 & 0.04 \\
$7.62 \mathrm{~mm}$ & 0.093 & 0.093 & 1.8 & 3.0 & 0.17 & 0.2 \\
$12.7 \mathrm{~mm}$ & 0.37 & 0.093 & 10.6 & 17.3 & 3.3 & 1.3 \\
\hline
\end{tabular}

* Assumes projectile deformed to a strain of 1.0

\# Assumes all projectile material ejected with velocity of fine debris

Although the projectile impact causes fragments to be ejected with a considerable velocity in the opposite direction to projectile travel, momentum is conserved in the interaction by the small forward velocity of the centre of mass of the bulk of the brick. The forward velocity of the brick centre of mass, $v$, is related to the impacting projectile mass, $\mathrm{m}$, and velocity, $\mathrm{v}_{\mathrm{o}}$, and to the brick mass, $M$, by an equation of the form

$$
\mathrm{v}=\mathrm{C} \frac{\mathrm{m}}{\mathrm{M}} \mathrm{v}_{0}
$$

where $C$ is a parameter dependent on the relative mass of high speed ejecta to the impacting projectile mass, and to the inelastic work done. For typical ejecta masses and for the low value of inelastic work in the present case, $C$ is in the range 2 to 5 . Use of equation (1) with the projectile impact momentum and the brick mass of $3.8 \mathrm{~kg}$, gives estimates of brick translation velocity of the correct order of magnitude. The video sequence of Figure 1 shows that motion of the centre of mass of the brick is not just forward but upward at an angle. This is because of the reaction when the stress wave reaches the steel rest on which the brick is standing.

The expansion velocity of the debris results from the conversion of elastic strain energy to kinetic energy. Using a simplified fracture toughness analysis the fracture stress, $\sigma$, can be estimated from the toughness, $\mathrm{K}_{\mathrm{Ic}}$, and an assumed half crack length, a, by

$$
\sigma=K_{\text {Ic }} / \sqrt{ }(\pi \mathrm{a})
$$

Combining the toughness figure for the clay brick in Table I with an estimated value for a of 1 $\mathrm{mm}$ gives a fracture stress of $18 \mathrm{MPa}$. By equating kinetic energy to elastic strain energy the fragment velocity, $v$, becomes

$$
\mathrm{v}=\sigma / \sqrt{ }(\rho \mathrm{E})
$$

where $\rho$ is the material density and $\mathrm{E}$ is the elastic modulus. For typical values of $\rho$ and $\mathrm{E}$ and the above fracture stress, a figure of $4 \mathrm{~ms}^{-1}$ results for the velocity of the expanding fragments. 
Higher intensity impacts can be seen as inducing higher compressive stresses in the brick, which reflect as higher tensile stresses, activating smaller flaws. Thus higher intensity impacts should produce more fragmentation, because of the greater number of flaws which propagate, and higher expansion velocities, because of the higher stress level.

The sequence of events in fragmentation is then shown in Figure 3. Initially, Figure 3(a), the impact produces both fine high velocity debris by comminution and a slow forward motion of material behind an expanding compressive stress wave. Relief waves are reflected from the free surfaces and the projectile comes to rest within material which is now moving forward with a low velocity. Finally fragmentation of the brick results from interaction of the relief waves, Fig. 3(c), and the degree of fragmentation is controlled by the stress level which determines the size of flaw which is activated.

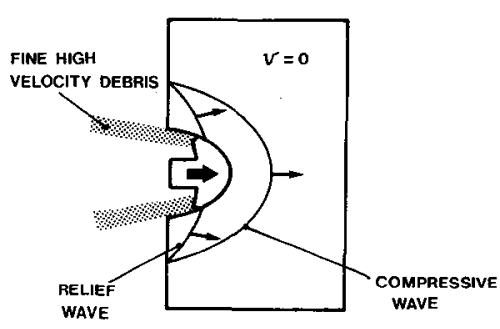

(a)

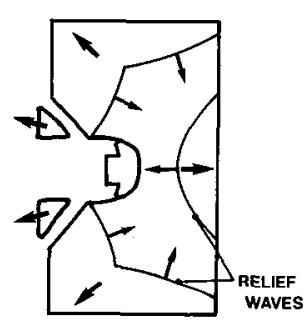

(b)

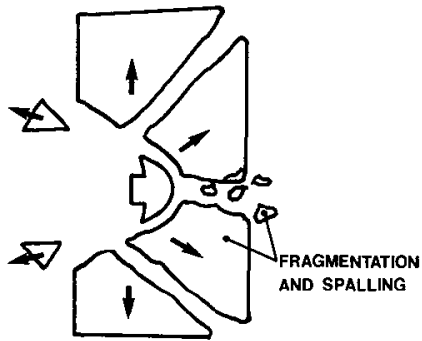

(c)

Fig. 3 Schematic sequence of events in impact. (a) Immediately after impact, projectile penetrating with the ejection of fine debris and acceleration of material behind the stress wave. (b) Penetration has ceased and relief waves have propagated from the distal surfaces. (c) Interacting relief waves cause fragmentation and spalling.

\section{Conclusion}

This study of projectile impact on "semi-infinite" brittle materials has illustrated the mechanisms by which projectile and target interaction and erosion cause the projectile to slow, transferring its energy to fine ceramic debris which is ejected. The majority of the very fine debris is ejected from the area near the crater. Reflection of stress waves from distal surfaces can lead to further spalling and fragmentation away from the impact site, with the degree of break-up being controlled by the intensity of impact which governs what size flaws lead to fracture. The forward velocity following impact is controlled by conservation of momentum and the expansion velocity by the conversion of elastic strain energy to kinetic energy.

\section{References}

1. Wilkins, M.L. In R.C. Laible (Ed). Ballistic Materials and Penetration Mechanics, Elsevier Sci. Pub. Co., (1980) 225.

2. Roddy, D.J., Schuster, S.A., Rosenblatt, M., Grant, L.B., Hassig, P.J. and K.N. Kreyenhagen, Int. J. Impact Engng. 5 (1987), 525.

3. Grady, D.E., J. Mech. Phys. Sol. 36 (1988), 353.

4. Grady, D.E. and Kipp, M.E., In T. Wierzbicki (Ed) Structural Failure, J. Wiley \& Sons Inc. (1989) 1.

5. Woodward, R.L., O'Donnell, R.G., Baxter, B.J., Nicol, B. and Pattie, S.D. Materials Forum 13 (1989) 174.

6. Gault, D.E. and Heitowit, E.D., Proc. of the Sixth Symposium on Hypervelocity Impact, Vol. II, Part 2, August (1963), 419.

7. Woodward, R.L. Int. J. Impact. Engng. 9 (1990) 455. 